\title{
The Challenges of COVID-19 for People Living With Diabetes: Considerations for Digital Health
}

Anissa Gamble ${ }^{1}$, MSc; Quynh Pham ${ }^{1,2}, \mathrm{PhD}$; Shivani Goyal ${ }^{1,2}$, PhD; Joseph A Cafazzo ${ }^{1,2,3}$, PEng, PhD

${ }^{1}$ Centre for Global eHealth Innovation, Techna Institute, University Health Network, Toronto, ON, Canada

${ }^{2}$ Institute of Health Policy, Management and Evaluation, Dalla Lana School of Public Health, University of Toronto, Toronto, ON, Canada

${ }^{3}$ Institute of Biomaterials and Biomedical Engineering, University of Toronto, Toronto, ON, Canada

\section{Corresponding Author:}

Anissa Gamble, MSc

Centre for Global eHealth Innovation

Techna Institute

University Health Network

190 Elizabeth Street, 4th Floor R Fraser Elliot Building

Toronto, ON, M5G2C4

Canada

Phone: 1 (416) 3404800 ext 4765

Email: anissa.gamble@uhn.ca

\begin{abstract}
The coronavirus disease (COVID-19) is a global pandemic that significantly impacts people living with diabetes. Diabetes-related factors of glycemic control, medication pharmacodynamics, and insulin access can impact the severity of a COVID-19 infection. In this commentary, we explore how digital health can support the diabetes community through the pandemic. For those living with diabetes, digital health presents the opportunity to access care with greater convenience while not having to expose themselves to infection in an in-person clinic. Digital diabetes apps can increase agency in self-care and produce clinically significant improvement in glycemic control through facilitating the capture of diabetes device data. However, the ability to share these data back to the clinic to inform virtual care and enhance diabetes coaching and guidance remains a challenge. In the end, it requires an unnecessarily high level of technical sophistication on the clinic's part and on those living with diabetes to routinely use their diabetes device data in clinic visits, virtual or otherwise. As the world comes together to fight the COVID-19 pandemic, close collaboration among the global diabetes community is critical to understand and manage the sustained impact of the pandemic on people living with diabetes.
\end{abstract}

(JMIR Diabetes 2020;5(2):e19581) doi: 10.2196/19581

\section{KEYWORDS}

diabetes; digital health; COVID-19; pandemic

The coronavirus disease (COVID-19) is a global pandemic and significantly impacts individuals living with diabetes. In China, Wu and McGoogan [1] reported that people living with diabetes who contracted the virus had a more than triple mortality rate of $7 \%$ in comparison to $2 \%$ in those without diabetes. These figures align with previous global pandemics, which were also associated with increased morbidity and mortality in people with diabetes [2]. During the 2009 H1N1 pandemic, Canadians living with diabetes had triple the risk of hospitalization and quadruple the risk of intensive care unit admissions [3]. The 2003 severe acute respiratory syndrome epidemic also resulted in increased hospitalization and disease severity for people with diabetes [4,5]. As global pandemics continue to occur and the prevalence of diabetes increases [6], the diabetes community will be increasingly confronted with ongoing public health challenges [7].

The World Health Organization has warned that older adults and those with pre-existing medical conditions like diabetes are at higher risk of COVID-19 exposure, complications, and death [8]. Since the majority of the diabetes population are older [9] and have multiple comorbidities of obesity, emphysema, hypertension, and heart failure [10,11], they are at greater risk of viral infection. Although data on COVID-19 presentation has yet to support an increased risk of viral contraction in people living with diabetes $[12,13]$, evidence suggests that they may have worse outcomes should they contract the virus [13,14]. 
Poor glycemic control is a significant contributor to COVID-19 severity. Hyperglycemic events can lead to diabetes ketoacidosis, which is a life-threatening condition that interferes with the immune response to mitigate sepsis and recovery [15]. Coronaviruses have also been shown to bind to their target cells through angiotensin converting enzyme-2 (ACE2). Fang et al [16] proposed that the expression of ACE2 is substantially increased in people managing their diabetes with ACE inhibitors and antihyperglycemic angiotensin II type-I receptor blockers [17]. As such, these individuals may be at an increased risk of developing severe and fatal COVID-19. To maintain adequate glycemic control, people living with diabetes are normally encouraged to eat well, exercise, and maintain good mental health [18-20]. However, efforts to minimize the risk of exposure to COVID-19 have required social distancing and quarantine practices that may exacerbate insulin sensitivity through lower levels of physical activity, abrupt changes in social routine, poor dietary diversity, and diabetes distress [21-24].

Guidelines authored by prominent diabetes societies encourage the use of insulin as the preferred treatment during the global pandemic $[25,26]$. However, the impact of COVID-19 on the global economy has compromised insulin production and access [27]. For people who are insulin-dependent, the risk of an insulin shortage or delayed delivery is deadly [28]. Health professionals are recommending people to have a 30-day supply of diabetes medication and supplies for their medical devices [29]. This advice may prove difficult to heed for the growing population of people in both urban (10.8\%) and rural (7.2\%) settings who experience socioeconomic disparities, specifically lower income, as they may not be able to afford adhering to such guidelines $[13,30,31]$. In addition, the shortage of commercial antibacterial products may impede sterilization techniques for insulin injections and blood glucose monitoring, and promote infection [32]. Significant decreases in traditional in-person clinic availability will require people to adopt and adjust to receiving digital diabetes care [33].

In response to social distancing guidance, outpatient diabetes clinics and family medicine practices have greatly curtailed their services to only the most urgent cases [34]. Even as restrictions are expected to ease over time, there will be continued caution in visiting clinics. In light of these circumstances, the use of previously restricted forms of communication between providers and their patients have been allowed. Most forms of audio, video, or texting technology have been allowed by jurisdictions through not only relaxing privacy and security requirements but also reimbursing providers for these services. Even telephone calls have become an accepted modality for conducting a clinical visit, allowing those without sophisticated consumer devices like smartphones to access services [35-37].

For those living with diabetes, this is an opportunity to be able to access care with greater convenience while not having to expose themselves to infection in an in-person clinic. If the use of virtual visits continues after the pandemic eases - as they are expected to [38] -it opens up a great opportunity to provide more timely access to not only physician care but services that are often scarce for those living with diabetes [39]. With physical distances no longer a factor, virtualizing the care provided by diabetes educators, dieticians, and specialized mental health professionals could improve access further than what was previously possible with in-person encounters [40]. These successes can only be realized if broader digital health inequities of access and literacy are addressed within the diabetes community [41].

Perhaps more compelling than improving access to health services through virtual care, digital health apps can also create greater agency in self-care. A series of studies in recent years have demonstrated that diabetes smartphone apps with the ability to capture diabetes data and other self-reported factors can produce clinically significant improvement in glycemic control for both those living with type 1 diabetes and type 2 diabetes $[40,42,43]$. These outcomes were achieved without the benefit of a provider facilitating care through the app. Additional studies have since shown that outcomes can be further enhanced with the addition of virtual care and the active use of diabetes data sharing to enhance diabetes coaching and guidance $[44,45]$.

Despite the positive enablers for remote diabetes care, the ability to share diabetes device data back to the clinic remains a challenge [46]. As it stands, the current landscape of diabetes device data interoperability is a patchwork of proprietary technologies, open source tools, and restrictive electronic health record (EHR) policies. In the end, it requires an unnecessarily high level of technical sophistication on the clinic's part and on those living with diabetes to routinely use their diabetes device data in clinic visits, virtual or otherwise [47-49]. This technical burden will simply continue to hamper efforts to facilitate comprehensive virtual care. It continues to be a challenge to convince manufacturers of diabetes devices and EHR vendors to create truly interoperable systems to ease the burden on the diabetes communities [40]. It is hoped that the pandemic further reveals the flaws of the industry's business tactics to maintain exclusivity and their slow response in addressing the needs of the diabetes community.

As the world comes together to fight the COVID-19 pandemic, close collaboration among the global diabetes community is critical to understand and manage the sustained impact of the pandemic on people living with diabetes. Figure 1 presents a summary of the challenges of COVID-19 for people living with diabetes and the opportunities of diabetes digital health to support them in this time of need. Contribution and access to trusted diabetes resources that can communicate actionable insights on the status of COVID-19 are needed to support the community through these challenging times [12,13,50-55]. 
Figure 1. The challenges of COVID-19 for people living with diabetes and the opportunities of diabetes digital health.

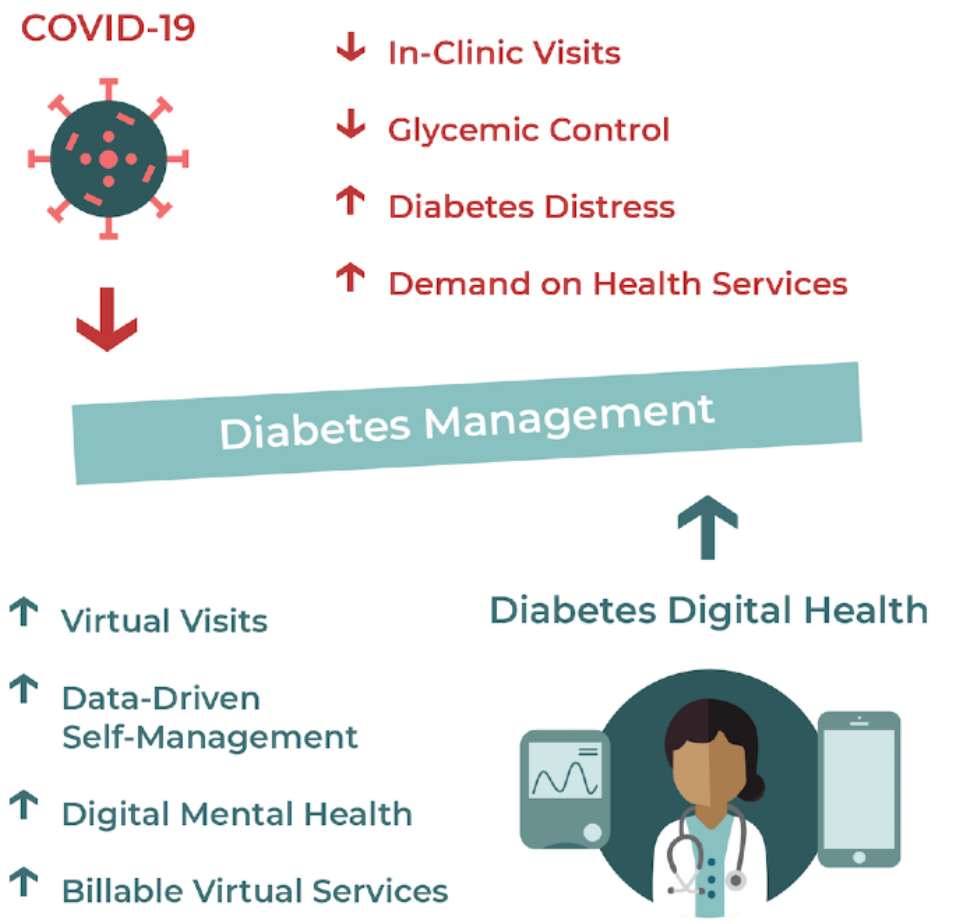

\section{Conflicts of Interest}

None declared.

\section{References}

1. Wu Z, McGoogan JM. Characteristics of and important lessons from the coronavirus disease 2019 (COVID-19) Outbreak in China: summary of a report of 72314 cases from the Chinese Center for Disease Control and Prevention. JAMA 2020 Feb 24. [doi: 10.1001/jama.2020.2648] [Medline: $\underline{32091533}$ ]

2. CDC COVID-19 Response Team. Preliminary estimates of the prevalence of selected underlying health conditions among patients with coronavirus disease 2019 - United States, February 12-March 28, 2020. MMWR Morb Mortal Wkly Rep 2020 Apr 03;69(13):382-386. [doi: 10.15585/mmwr.mm6913e2] [Medline: 32240123]

3. Allard R, Leclerc P, Tremblay C, Tannenbaum T. Diabetes and the severity of pandemic influenza A (H1N1) infection. Diabetes Care 2010 Jul;33(7):1491-1493 [FREE Full text] [doi: 10.2337/dc09-2215] [Medline: 20587722]

4. World Health Organization. SARS (severe acute respiratory syndrome) URL: https://www.who.int/ith/diseases/sars/en/

5. Dodek P. Diabetes and other comorbid conditions were associated with a poor outcome in SARS. ACP J Club 2004 Jan 01;140(1):19 [FREE Full text]

6. International Diabetes Federation. 2019. IDF diabetes atlas 9th edition URL: https://www.diabetesatlas.org/en/

7. Hill MA, Mantzoros C, Sowers JR. Commentary: COVID-19 in patients with diabetes. Metabolism 2020 Mar 24;107:154217 [FREE Full text] [doi: 10.1016/j.metabol.2020.154217] [Medline: 32220611]

8. World Health Organization. Coronavirus disease (COVID-19) pandemic URL: https://www.who.int/emergencies/diseases/ novel-coronavirus-2019

9. Public Health Agency of Canada. 2017. Diabetes in Canada URL: https://www.canada.ca/en/public-health/services/ publications/diseases-conditions/diabetes-canada-highlights-chronic-disease-surveillance-system.html

10. Piette JD, Kerr EA. The impact of comorbid chronic conditions on diabetes care. Diabetes Care 2006 Mar;29(3):725-731. [doi: 10.2337/diacare.29.03.06.dc05-2078] [Medline: 16505540]

11. Zhu L, She Z, Cheng X, Qin J, Zhang X, Cai J, et al. Association of blood glucose control and outcomes in patients with COVID-19 and pre-existing type 2 diabetes. Cell Metab 2020 May 01. [doi: 10.1016/j.cmet.2020.04.021] [Medline: 32369736]

12. Diabetes Canada. 2020 May 12. FAQ about COVID-19 and diabetes URL: https://www.diabetes.ca/resources/ tools---resources/faq-about-covid-19-and-diabetes

13. American Diabetes Association. Diabetes and coronavirus URL: https://www.diabetes.org/coronavirus-covid-19

14. Hulme KD, Gallo LA, Short KR. Influenza virus and glycemic variability in diabetes: a killer combination? Front Microbiol 2017;8:861. [doi: 10.3389/fmicb.2017.00861] [Medline: 28588558] 
15. Diabetes Canada. 2020 Mar 06. Novel Coronavirus (COVID-19) and diabetes: what you should know URL: https://www. diabetes.ca/media-room/news/novel-coronavirus-(covid-19)-and-diabetes--what-you-should-know

16. Fang L, Karakiulakis G, Roth M. Are patients with hypertension and diabetes mellitus at increased risk for COVID-19 infection? Lancet Respir Med 2020 Apr;8(4):e21. [doi: 10.1016/s2213-2600(20)30116-8]

17. Kuster GM, Pfister O, Burkard T, Zhou Q, Twerenbold R, Haaf P, et al. SARS-CoV2: should inhibitors of the renin-angiotensin system be withdrawn in patients with COVID-19? Eur Heart J 2020 Mar 20 [FREE Full text] [doi: 10.1093/eurheartj/ehaa235] [Medline: 32196087]

18. Pallayova M, Taheri S. Targeting diabetes distress: the missing piece of the successful type 1 diabetes management puzzle. Diabetes Spectr 2014 May;27(2):143-149 [FREE Full text] [doi: 10.2337/diaspect.27.2.143] [Medline: 26246771]

19. Riddell MC, Gallen IW, Smart CE, Taplin CE, Adolfsson P, Lumb AN, et al. Exercise management in type 1 diabetes: a consensus statement. Lancet Diabetes Endocrinol 2017 May;5(5):377-390. [doi: 10.1016/s2213-8587(17)30014-1]

20. Gray A, Threlkeld RJ. Nutritional recommendations for individuals with diabetes. Endotext 2019. [Medline: 25905243]

21. Diabetes Canada. 2019 Nov 05. Food insecurity and diabetes URL: https://www.diabetes.ca/managing-my-diabetes/stories/ food-insecurity-and-diabetes

22. Zaharieva DP, McGaugh S, Davis EA, Riddell MC. Advances in exercise, physical activity, and diabetes. Diabetes Technol Ther 2020 Feb;22(S1):S109-S118. [doi: 10.1089/dia.2020.2508] [Medline: 32069147]

23. Diabetes Canada Clinical Practice Guidelines Expert Committee, Robinson DJ, Coons M, Haensel H, Vallis M, Yale JF. Diabetes and mental health. Can J Diabetes 2018 Apr;42 Suppl 1:S130-S141. [doi: 10.1016/j.jcjd.2017.10.031] [Medline: 29650085]

24. Gupta R, Ghosh A, Singh AK, Misra A. Clinical considerations for patients with diabetes in times of COVID-19 epidemic. Diabetes Metab Syndr 2020;14(3):211-212 [FREE Full text] [doi: 10.1016/j.dsx.2020.03.002] [Medline: 32172175]

25. JDRF-Beyond Type 1 Alliance. Coronavirus + Diabetes URL: https://tinyurl.com/ybcp5dn7

26. Bornstein SR, Rubino F, Khunti K, Mingrone G, Hopkins D, Birkenfeld AL, et al. Practical recommendations for the management of diabetes in patients with COVID-19. Lancet Diabetes Endocrinol 2020 Apr. [doi: 10.1016/S2213-8587(20)30152-2]

27. Cefalu WT, Dawes DE, Gavlak G, Goldman D, Herman WH, Van Nuys K, Insulin Access and Affordability Working Group. Insulin access and affordability working group: conclusions and recommendations. Diabetes Care 2018 Jun;41(6):1299-1311. [doi: 10.2337/dci18-0019] [Medline: 29739814]

28. Healio. 2020 Mar 16. Extra insulin supplies, medications advised for people with diabetes in wake of COVID-19 URL: https://www.healio.com/endocrinology/diabetes/news/online/\%7B19b3e970-b54c-499b-8cfa-01591e7bcd6b\%7D/ extra-insulin-supplies-medications-advised-for-people-with-diabetes-in-wake-of-covid-19

29. Diabetes Canada. 2020 Mar 23. An open letter: working together to avoid diabetes supply interruptions during Covid-19 pandemic URL: https://www.diabetes.ca/media-room/news/ an-open-letter--working-together-to-avoid-diabetes-supply-interruptions-during-covid-19-pandemic

30. Saydah SH, Imperatore G, Beckles GL. Socioeconomic status and mortality: contribution of health care access and psychological distress among U.S. adults with diagnosed diabetes. Diabetes Care 2013 Jan;36(1):49-55 [FREE Full text] [doi: 10.2337/dc11-1864] [Medline: 22933434]

31. International Diabetes Federation. Worldwide toll of diabetes URL: https://diabetesatlas.org/en/sections/ worldwide-toll-of-diabetes.html

32. Finucane K, Ambrey P, Narayan S, Archer CB, Dayan C. Insulin injection abscesses caused by Mycobacterium chelonae. Diabetes Care 2003 Aug;26(8):2483-2484. [doi: 10.2337/diacare.26.8.2483] [Medline: 12882896]

33. Women's College Hospital. Centre for integrated diabetes care URL: https://www.womenscollegehospital.ca/care-programs/ centre-for-integrated-diabetes-care

34. Public Health Agency of Canada. 2020. Coronavirus disease (COVID-19): for health professionals URL: https://www. canada.ca/en/public-health/services/diseases/2019-novel-coronavirus-infection/health-professionals.html

35. Dawkins G. Winnipeg Sun. 2020 Mar 16. Manitoba doctors will be able to offer patient visits over telephone, videoconferencing URL: https://winnipegsun.com/news/news-news/ manitoba-doctors-will-be-able-to-offer-patient-visits-over-telephone-videoconferencing

36. American College of Physicians. 2020 Mar 31. Internists commend CMS decision to pay for telephone visits to help physician practices during COVID-19 emergency URL: https://www.acponline.org/acp-newsroom/ internists-commend-cms-decision-to-pay-for-telephone-visits-to-help-physician-practices-during-covid

37. Favaro A, St Philip E. CTV News. 2020 Mar 14. Ontario implements virtual medical visits in bid to keep doctors, patients safe amid COVID-19 URL: https://www.ctvnews.ca/health/coronavirus/ ontario-implements-virtual-medical-visits-in-bid-to-keep-doctors-patients-safe-amid-covid-19-1.4853436

38. Barron D. Scientific American. 2020 Mar 21. Has telemedicine's day finally come? URL: https://blogs.scientificamerican.com/ observations/has-telemedicines-day-finally-come/

39. Iyengar V, Wolf A, Brown A, Close K. Challenges in diabetes care: can digital health help address them? Clin Diabetes 2016 Jul;34(3):133-141 [FREE Full text] [doi: 10.2337/diaclin.34.3.133] [Medline: 27621530] 
40. Cafazzo JA. A digital-first model of diabetes care. Diabetes Technol Ther 2019 Jun;21(S2):S252-S258. [doi: 10.1089/dia.2019.0058] [Medline: 31169428 ]

41. Nouri S, Khoong EC, Lyles CR, Karliner L. Addressing equity in telemedicine for chronic disease management during the Covid-19 pandemic. NEJM Catalyst 2020 May 04.

42. Wu Y, Yao X, Vespasiani G, Nicolucci A, Dong Y, Kwong J, et al. Mobile app-based interventions to support diabetes self-management: a systematic review of randomized controlled trials to identify functions associated with glycemic efficacy. JMIR Mhealth Uhealth 2017 Mar 14;5(3):e35. [doi: 10.2196/mhealth.6522] [Medline: 28292740]

43. Kitsiou S, Paré G, Jaana M, Gerber B. Effectiveness of mHealth interventions for patients with diabetes: an overview of systematic reviews. PLoS One 2017;12(3):e0173160. [doi: 10.1371/journal.pone.0173160] [Medline: 28249025]

44. Greenwood DA, Blozis SA, Young HM, Nesbitt TS, Quinn CC. Overcoming clinical inertia: a randomized clinical trial of a telehealth remote monitoring intervention using paired glucose testing in adults with type 2 diabetes. J Med Internet Res 2015 Jul 21;17(7):e178. [doi: 10.2196/jmir.4112] [Medline: 26199142]

45. McDonnell ME. Telemedicine in complex diabetes management. Curr Diab Rep 2018 May 24;18(7):42. [doi: 10.1007/s11892-018-1015-3] [Medline: 29797292]

46. Arbiter B, Look H, McComb L, Snider C. Why download data: the benefits and challenges of more diabetes data. Diabetes Spectr 2019 Aug;32(3):221-225. [doi: 10.2337/ds18-0099] [Medline: 31462877]

47. Wong JC, Neinstein AB, Spindler M, Adi S. A minority of patients with type 1 diabetes routinely downloads and retrospectively reviews device data. Diabetes Technol Ther 2015 Aug;17(8):555-562 [FREE Full text] [doi: 10.1089/dia.2014.0413] [Medline: 26133226]

48. Neinstein A, Wong J, Look H, Arbiter B, Quirk K, McCanne S, et al. A case study in open source innovation: developing the Tidepool Platform for interoperability in type 1 diabetes management. J Am Med Inform Assoc 2016 Mar;23(2):324-332 [FREE Full text] [doi: 10.1093/jamia/ocv104] [Medline: 26338218]

49. Schramm W. Digital diabetes self-management: a trilateral serial. J Diabetes Sci Technol 2018 May;12(3):709-711 [FREE Full text] [doi: 10.1177/1932296818761973] [Medline: 29514509]

50. Jen. Connected in Motion. 2020 Mar 13. Keeping our diabetes community healthy: COVID-19 URL: https://www. connectedinmotion.ca/blog/cim-covid-19-update/

51. LMC Healthcare. 2020 Mar 16. COVID-19 Update From LMC URL: https://www.lmc.ca/news/covid-19-update-from-lmc/

52. Healthline. URL: https://www.healthline.com/

53. Alkon C. diaTribe. 2020 Mar 11. What you need to know about diabetes and the coronavirus URL: https://diatribe.org/ what-you-need-know-about-diabetes-and-coronavirus

54. Seitz S. Insulin Nation. 2020 Mar 04. Coronavirus and T1D: what you need to know and how to prepare URL: https:/ /insulinnation.com/living/coronavirus-and-t1d-what-you-need-to-know-and-how-to-prepare/

55. JDRF. T1D and coronavirus: what you need to know URL: https://www.jdrf.ca/coronavirus/

\section{Abbreviations}

ACE2: angiotensin converting enzyme-2

COVID-19: coronavirus disease

EHR: electronic health record

Edited by G Eysenbach; submitted 28.04.20; peer-reviewed by G Fagherazzi, M Mitchell; comments to author 04.05.20; revised
version received 10.05.20; accepted 11.05.20; published 15.05.20
Please cite as:
Gamble A, Pham Q, Goyal S, Cafazzo JA
The Challenges of COVID-19 for People Living With Diabetes: Considerations for Digital Health
JMIR Diabetes 2020;5(2):e19581
URL: $\underline{\text { http://diabetes.jmir.org/2020/2/e19581/ }}$
doi: $\underline{10.2196 / 19581}$
PMID: $\underline{32392473}$

(C)Anissa Gamble, Quynh Pham, Shivani Goyal, Joseph A Cafazzo. Originally published in JMIR Diabetes (http://diabetes.jmir.org), 15.05.2020. This is an open-access article distributed under the terms of the Creative Commons Attribution License (https://creativecommons.org/licenses/by/4.0/), which permits unrestricted use, distribution, and reproduction in any medium, provided the original work, first published in JMIR Diabetes, is properly cited. The complete bibliographic information, a link to the original publication on http://diabetes.jmir.org/, as well as this copyright and license information must be included. 